\title{
眼窩吹き抜け骨折の手術
}

鴻信義山口展正

要旨：当教室における眼窩吹き抜け骨折症例について検討を行った。1 週間程度の保存療法にて複視や 眼球運動時痛などが改善しない場合, 整復術を施行する。内側壁骨折は経鼻的に, また下壁骨折は経上 顎洞的（可能であれば経鼻的）に整復し, シリコン板やバルーンカテーテルを用いて固定する。局所麻 酔下での手術は, 術中に自覚症状の改善の有無が確認できる利点がある。小児の骨折や患者の希望など により全身麻酔を選択する場合, 十分な範囲での骨折片の除去が要求される。術後経過は概ね良好であ るが, 眼窩内容物が骨折片で絞扼されている症例では, 手術を施行しても改善が思わしくない事が少な くない。受傷時の眼窩内組織の損傷程度も予後を左右すると考える。

キーワード：眼窩吹き抜け骨折，内視鏡下鼻内手術，眼球運動障害，複視

\section{Summary Endoscopic repair of orbital blowout fractures :}

Otori Nobuyoshi and Yamaguchi Nobumasa. Dept. of Otorhinolaryngology, Jikei University Hospital, 3-25-8, Nishi-shinbashi, Minato-Ku, Tokyo, Japan

We reviewed cases of orbital blow-out fracture, which were endoscopically operated upon in our institution in the 1990s (229 cases). When diplopia and/or disturbed eye movement could not be improved after one week's conservative treatment, we performed endoscopic surgery as follows. Fracture of the lamina papyracea was repaired endonasally and fixed with a silicone plate and gauze packing. Fracture of the orbital floor was repaired either endonasally or trans-maxillarily and fixed with a balloon catheter.

In the case of surgery performed under local anesthesia, improvement of the patient's complaints was able to be confirmed even during the surgery. However, when we have to perform surgery under general anesthesia, such as in a child, sufficient removal of the fractured bone as well as the traction test during surgery ts needed.

Post-operative improvement was evaluated on the bases of an ophthalmologic examination and the change in the patient's subjective symptoms. In about $90 \%$ of all cases, a good clinical course was achieved. When the fracture occurred in a narrow area, so that the intra-orbital content was got between fractured bones, the post-operative improvement tended to be insufficient. We, therefore, concluded that the prognosis after the operation depends, to some extent, on the severity of the injury to the orbital content at the time of the injury.

Key words: orbital blowout fracture, endoscopic sinus surgery, diplopia, eye movement disturbance.

\footnotetext{
${ }^{*}$ 東京慈恵会医科大学耳鼻咽唉科学教室
} 


\section{1.はじめに}

眼窩吹き抜け骨折（blowout fracture，以下 $\mathrm{BOF}$ とする）は, CT や MRI など画像診断技術 の向上や, 副鼻腔の発育が良好となってきたこと などにより，近年増加傾向にある疾患である。本 疾患に対する手術療法には, 下眼瞼を切開し経眼 窩的に整復を行う方法 ${ }^{1,2)}$ と，副鼻腔手術に準じ て鼻内的，あるいは経上顎洞的に整復する方 法 ${ }^{3-8)}$ に大別される。近年の硬性内視鏡を用いた 鼻副鼻腔手術の発達に伴い, 耳鼻咽喉科医による 経鼻的な整復術が広く普及してきている。本稿で は, 当教室に扔ける BOF 手術症例について, 手 術適応, 術式, 術後成績などについて検討した。

\section{対象症例}

対象は, 1990 年より 1999 年までの間に, 慈恵 医大附属病院および慈恵医大付属青砥病院におい て手術を施行したBOF229 症例であった。手術時 年齢は 4 歳から 76 歳である。受傷機転としては, 傷害が 94 例 $(41 \%)$ と最も多く, 次いでボクシ ングやラグビーなどのスポーッ外傷が 71 例 (31\%) であった。大半の症例は，まず眼科を受 診し, 眼球運動あるいは Hess 赤緑試験などの眼 科学的検查所見，および画像所見より BOF との 診断を受け，当科へ紹介された。

骨折部位は, 眼窩内側壁 64 例 $(28 \%)$ ，眼窩下 壁 108 例（47\%），また内側壁と下壁の混合骨折 が 57 例 (25\%) であり，全体の $72 \%$ で眼窩下壁 に骨折を認めた（表 1)。ただし，症例を年齢より， 4-14 歳, 15-19 歳, および 20 歳以上の 3 群に分 類すると，4-14 歳の若年齢に発生した BOF では, 下壁単独の骨折が他の群に比較して多くみられた。

また眼窩下壁の骨折を，手術時の所見より，狭 い範囲の骨折と広い範囲の骨折に分類すると，そ れぞれ 71 例 $(31 \%$ ）と 158 例 $(69 \%)$ であった （表 2)。4-14 歳，15-19 歳，および 20 歳以上の 3 群間で下壁骨折の範囲を比較すると，4-14 歳の若 年齢では, 他の群と比較して狭い範囲での骨折が 多く見られた。

\section{BOF の手術適応}

当教室では, $\mathrm{BOF}$ の手術適応を以下のように
表 1 骨折部位と年齢

全体 $(n=229)$

$28 \% \quad 25 \%$

$47 \%$

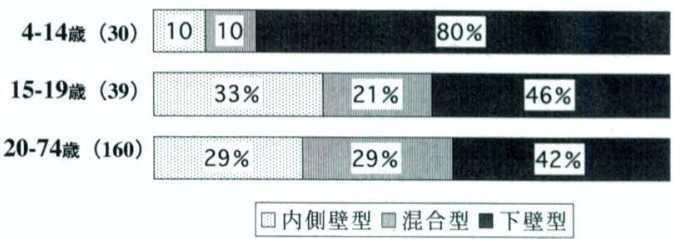

表 2 下壁骨折のタイプと年齢

全体 $(\mathbf{n}=165) \quad 31 \% \quad 69 \%$

\begin{tabular}{|c|c|c|}
\hline 4-14歳 (27) & $67 \%$ & $33 \%$ \\
\hline 15-19歳（26） & $50 \%$ & $50 \%$ \\
\hline 20-74藏（114） & $19 \%$ & \\
\hline
\end{tabular}

考えている。すなわち，1）複視あるいは眼球運 動障害・運動時痛が存在し，2）CT, MRIにて BOF が確認された症例に対し，3）1 週間程度の 保存療法を行っても症状の改善が認められない場 合，手術療法を選択するようにしている。従って 対象症例の $70 \%$ は, 受傷後 2 週間以内に手術が施 行された。

視機能の障害がなくとも, 眼窩内容の副鼻腔へ の広範な逸脱により, 将来的に副鼻腔炎 ${ }^{8,9)}$ や眼 球陥凹 ${ }^{6)}$ などが惹起される可能性が高いと判断し た場合も，手術の適応としている。また，受傷後 数ケ月が経過している陳旧性 $\mathrm{BOF}^{10)}$ であっても, 自他覚所見が存在し，患者の充分な同意が得られ れば手術を施行している。

\section{手術方法}

実際の手術方法は，参考文献 ${ }^{5)} に$ 記してあるの で, 本稿では術式の詳細についての記述は避ける。 手術の要点は, 骨折片と眼窩内容物との絞扼 . 癒着部を完全に解離し, 円滑な眼球運動を再獲得 させる事にある ${ }^{3-5,11)}$ 。内側壁骨折は，0.3-0.5mm のシリコンプレートおよびタンポンガーゼにて固 定し，下壁骨折は，バルンカテーテルにて固定す 
る。いずれも固定期間は 1 週間程度としている。 内側壁骨折は内視鏡下鼻内手術（ESS）で整復 が可能であるが，下壁骨折に対しては，症例によ り ESSを施行する場合と、ルックの手術に準じて 経上顎洞的に整復術を行う場合とがある。すなわ ち, 骨折部位が上顎洞膜様部に近ければ，膜様部 あるいは下鼻道経由で充分な手術操作が可能であ る。自験例においては下壁骨折に対して，32\%の 症例で ESSによる整復術を，また $68 \%$ 症例で 経上顎洞的整復術を行った。傾向として，最近は ESSにより整復した下壁骨折症例が増えている。 ただし，手術の目的は骨折の適切な整復であり， 術者の慣れた術式を選択すればよく，基本的に 2 つの手術方法に優劣ははないと考える9 。

眼窩内容物より解離した骨片は，可能であれば 除去せずに戻しておいたほうが良い。しかし，戻 した骨片により，却って眼窩骨膜や眼窩内容物と の間に新たな癒着・絞扼を生じる可能性が考えら れる場合，あるいは固定時の邪魔になるような場 合は, 無理に戻す必要はない9 。よほど大きな範 囲での骨折片除去でなければ，再生副鼻腔粘膜お よび結合組織のみで，十分に眼窩の支持組織とな ると考える。ただしプロボクサーなど，一部の特 殊な環境にある患者（再受傷の可能性がある）で は，なるべく骨片を戻すようにしている。

手術は可能であれば局所麻酔下に行うようにし ている。これは, 術中に自覚症状の改善程度が確 認できるため ${ }^{3,4)}$, 骨折片の除去が最小限ですむ からである。しかし小児の BOFや，成人でも患 者の希望があれば，全身麻酔を選択している。全 身麻酔の場合, 骨折片の除去が十分かどうかは, traction testの所見より判断せざるを得ない。 我々は，骨折片を周囲の骨も含め，少し大きめに
除去するようにしている。

成人の内側壁骨折は，ほとんど局所麻酔で問題 なく手術が施行できる。一方下壁骨折では，特に 下眼窩神経が骨折部位に挟まれる場合，骨片を除 去する際の疼痛が強く ${ }^{9)}$, 全身麻酔が望ましい症 例が少なくない。また陳旧性 BOF では，骨折部 位周囲が癒着していることが多く10)，やはり全身 麻酔が望ましいと考える。自験例では局所麻酔下 の手術が全体の $43 \%$ ，全身麻酔が $57 \%$ であった が，最近は（特に下壁骨折は）全身麻酔を選択す る症例が増えてきている。

\section{術後成績}

BOF の術後成績は, 自覚症状および Hess 赤緑 試験より評価しており, 特に患者の自覚症状の変 化を，重点的に観察している。自覚症状がほぼ完 全に消失した症例を治癒，術前より改善したが症 状が多少残存した症例を軽快，また症状の改善が みられなかった症例を不変とし, 術後成績を検討 した。今回対象とした BOF229 例において, 治癒 が $88 \%$ ，軽快が $9 \%$ ，不変が $3 \%$ あった（表 3 )。 骨折部位別に術後成績をみると，内側壁骨折では 全例で治癒が得られていたが，下壁骨折では治瘉 は89\%であった。しかし内側壁と下壁の混合型骨

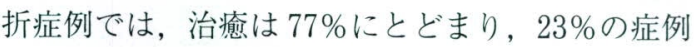
において自覚症状の残存が認められた。

軽快および不変例において, 術後に残存した自 覚症状としては, 上方視時の複視が最も多かった。 狭い範囲の下壁骨折症例に, 軽快掞上び不変例が 比較的多くみられたが，広い範囲の下壁骨折であっ ても術後に自覚症状が残存した症例が存在した。 また，不変例の内 4 例で再手術を施行し，骨折片 の除去を再度十分に行った。このうち 2 例では,

表 3 自覚症状からみた術後成績

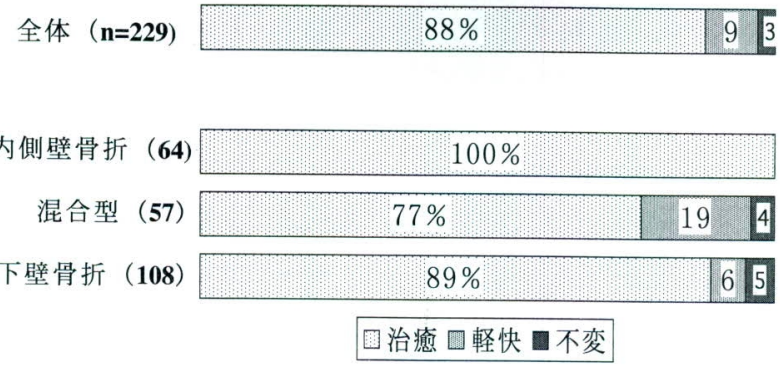


再手術後に症状の改善をみているが，2 例では， 自覚症状に何らの改善も認められなかった。

以下に, 実際の BOF 手術症例を提示する。 (症例提示)

症例 1.9 歳 男児

現病歴：1999 年 7 月 3 日, 小学校で同級生に, 左眼を膝で蹴り上げられた。直後より, 左眼球上 転制限（図 1）および上方視時の複視を認めたた め, 当科眼科を受診, 左眼窩下壁骨折と診断され 当科を紹介された。保存療法にて経過を観察した が, 症状の改善がみられなかったため, 当科に入 院となり，7月 13 日に全身麻酔下に経鼻的整復術 を施行した。

手術所見：眼窩下壁より，狭い範囲での眼窩内 容物の逸脱を認めた。上顎洞膜様部および下鼻道 より鉗子を挿入して骨折片を除去し， traction test での改善を確認したのち, 眼窩内容物をバ ルンにて眼窩内へ押し戻して固定した。

術後経過：手術 1 週間後にバルンを抜去した。 抜去後上転制限および複視の消失が認められた (図 1)。

\section{症例 2. 17 歳 男性}

現病歴 : 1999 年 3 月 30 日, ラグビーの試合中 に他選手の肘が右眼にぶつかり，直後より複視が 出現したため, 近医眼科を受診した。保存療法に て経過を観察されていたが, 症状の改善がみられ ないため，4月 5 日当院眼科を紹介された。当院 初診時, 正面および上下方視にて複視があり，ま た右眼球に高度の上下運動障害を認めた。しかし， CT-scan では明らかな BOF を認めず（図 3), 精 査加療目的にて当科紹介され入院となった。入院 後 1 週間保存療法にて経過を観察したが, 依然改 善傾向がみられなかったため, 4 月 12 日に局所麻 酔下に経上顎洞的手術（試験的上顎洞開放術）を 行った。

手術所見 : 内視鏡にて上顎洞内を観察すると， 上顎洞膜様部近傍の眼窩下壁に, $6 \times 3 \mathrm{~mm}$ 程度の 狭い範囲での眼窩内容物の逸脱が認められた（図 4)。眼窩下壁の骨が線状に骨折しており，下直筋 がその中に絞扼されていると考えられた。骨折線 周囲の骨を十分に除去し, 眼窩内容を眼窩内へと 押し戻した。この時点では, 患者の自覚症状には ほとんど改善がみられなかったが, 疼痛が強く,

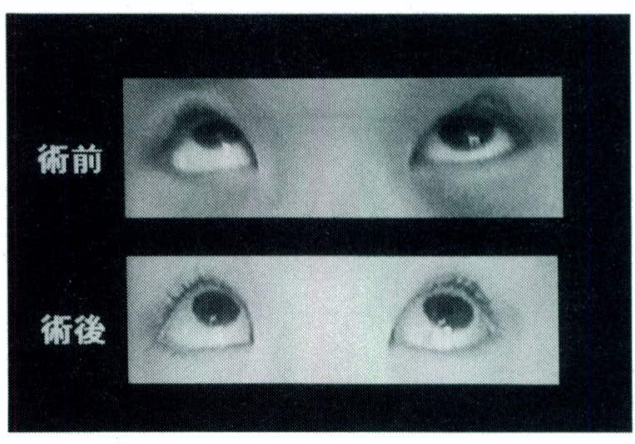

図 1 症例 1 の初診時（写真上）および整復術後 (写真下) の上方視時所見。初診時にみられ た左眼球上転制限は, 術後に改善している。

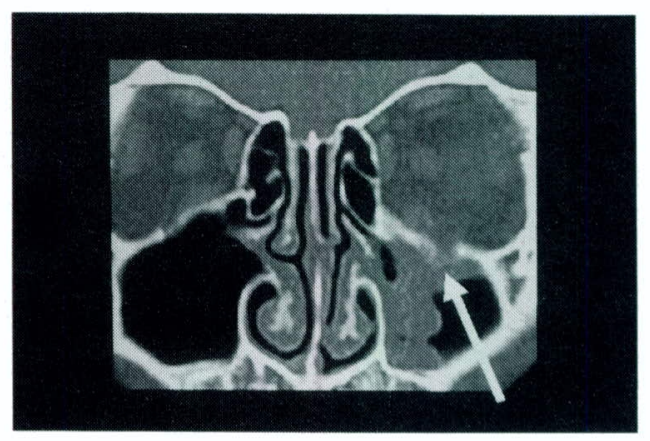

図 2 症例 1 の術前 CT-scan。左眼窩下壁に狭い 範囲での骨折と眼窩内容物の逸脱を認める (矢印)。

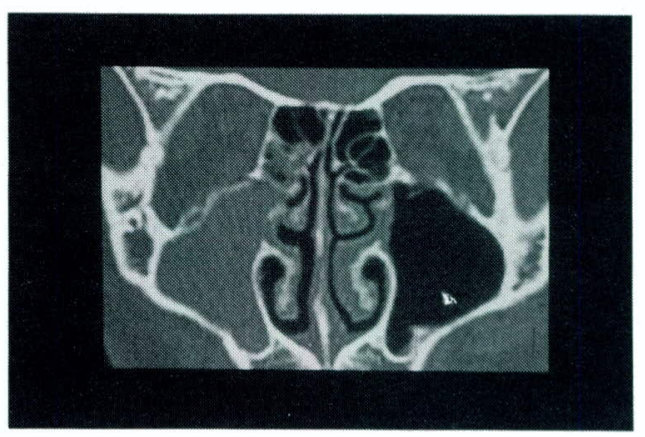

図 3 症例 2 の術前 CT-scan。右上顎洞内に貯留 液を認めるが，明らかな BOF はみられない。

また眼窩内容は完全に骨折片より解離されたと判 断したので, 手術を終了した。

術後経過 : 眼球運動障害は多少の改善をみたも のの, 複視はほとんど改善がないまま当科を退院 となり, 同年 8 月に当院眼科へ再度入院し, 眼位 


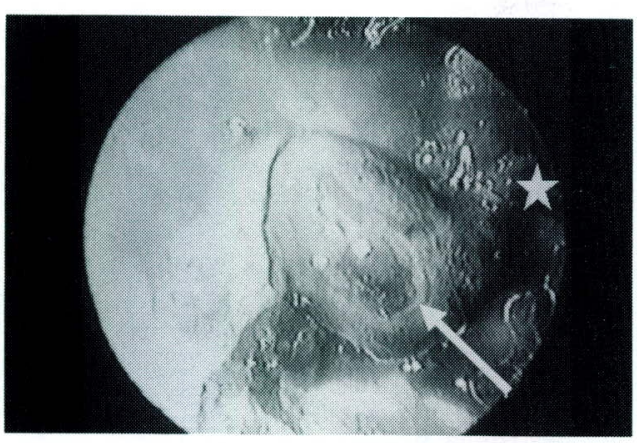

図 4 症例 2 の術中 0 度内視鏡所見。右眼窩下壁に 眼窩内容物（矢印）の逸脱を認める。(星印： 上顎洞膜様部)。

の矯正術が施行された。

\section{考察}

BOF は眼窩の骨折であるが, 副鼻腔の骨折の 一つと考えられ，その機能回復手術は皮膚切開を せずに，副鼻腔の手術に準じた方法で行うことが 理想である ${ }^{3,4)}$ 。内視鏡を用いて骨折部位を拡大 明視下におき，眼窩内容物を骨折片より適切に解 離することにより，多くの症例で良好な術後経過 が得られる。症例 1 のように，たとえ狭い範囲の 骨折であっても，十分に術後改善が期待できる。

しかし，狭い範囲に発生した下壁骨折症例でも， 眼窩内容物の絞扼が著明な場合，手術を十分に行っ ても術後改善が得られないことが多い。すなわち 眼窩内容物が, 受傷時の衝撃で瞬間的に骨折部位 から副鼻腔内へと逸脱し，その後骨折線の間隙に 絞扼されることで, 下直筋が挫滅や虚血性変化を 来たし, 非可逆的な状態となってしまう可能性が 考えられる ${ }^{12)}$ 。特に症例 2 のように, 受傷後の眼 球運動障害や複視が著明な症例では, 保存療法を 先行させず, なるべく早期の手術療法が必要であ る ${ }^{11-13)}$ 。なお症例 2 においては, 術前に MRIを 施行しておらず，CT ではBOF が確認できなかっ たために，診断が遅れてしまったという反省が残っ た。可能であれば CT と MRIの両者を術前に行 い, 骨折片の状態，および外眼筋や脂肪組織の偏 位の有無より, 総合的にBOF の病態を把握する べきであると考えた ${ }^{1,12)}$

術後経過が思わしくない症例で，主に上方視が 残存した理由として，下壁の骨折片の除去（特に
下壁後方の骨片の処置）が不十分であったと考元 られた症例がみられた。このような症例では, 再 手術を施行し, 骨片を再度十分に除去し, 眼窩内 容物が骨折部周囲の組織から完全に解離されてい る事を確認することで, 症状の改善が得られる場 合がある。患者の同意が得られれば，特に不変例 に対しては，再手術を行ってみる価値があると思 わ机る。

一方，広い範囲の骨折で, 眼窩内容物の明らか な絞扼がなくとも術後に改善が得られなかった症 例では, その原因は受傷時の衝撃による外眼筋の 損傷が高度であった，と結論付けざるを得ない事 がある。また，内側壁と下壁両方に骨折を認める 混合型骨折の術後成績が, 内側壁や下壁単独の骨 折と比較して不良なことより, 受傷時に眼窩内組 織がどの程度損傷されたかが, 少なからず術後改 善程度を決定すると考える。一般的には, 術前に, 術後の予後を的確に評価することは難しく，実際 の手術の施行に当たっては, 患者への十分なイン フォームドコンセントが肝要と考える。

BOF 手術において留意すべき点として，その 他以下のことが挙げられる。まず，術前に患者自 身が自発的眼球運動障害をしっかりと認識する必 要がある ${ }^{4)}$ 。すなわち術後評価を行う際，患者の 自覚症状の推移を正確に把握するためであり， か つ，手術をおこなう意味を患者自身に納得させる ためにも，重要な点である。

次に, 手術療法を行うと決定した場合, 陳旧化 しないうちに整復を行う方がよい $3,4,11)$ 。他施設 よりの報告では，受傷後 2 4 週間の保存療法を 扮こなった後に，手術療法の適応を考慮すること が多いようである ${ }^{6,12)}$ 。しかし, 受傷後一旦改善 が得られても, 数ヶ月経過した後に, 複視や眼球 運動時の引っかかり感, あるいは眼精疲労といっ た自覚症状が顕著になることがあり ${ }^{3,10)}$ ，初診時 より眼症状および画像上で明らかな BOF が確認 される症例では，積極的に手術療法を行うべきと 考える。

最後に，受傷原因として最も多い傷害事件によ る BOF 症例に対処する際には，患者はもちろん， 加害者側の社会的 · 心理的な背景も十分に考慮し たうえで，患者への説明や診断書の作成などにあ たり，余計なトラブルを引き起こすことのないよ 
うに注意が必要がある3)。

$$
\text { まとめ }
$$

BOF に対する内視鏡下整復術は，骨折部位の 整復・固定を適切かつ低侵襲に行う有用な方法で ある。手術の適応や術式は, 患者の病態, 背景, 術者の技量などにより決定されるが, 実際の手術 の施行に当たっては, 患者への十分なインフォー ムドコンセントが肝要である。BOF の病態, 症 状，また術後の経過は症例により様々である。一 症例一症例を積み重ね，特に術後改善が思わしく ない症例をみた時には，その原因を充分に考察し， 次の症例に反映していくことが大切であると考え る。

\section{参考文献}

1）平田行宏，出島健司，立本圭吾，他：幼児の眼窩底 吹き抜け骨折の 1 症例. JOHNS 14:613-616, 1998.

2）土師知行, 平本道昭, 大八木章博 : 眼窩壁骨折治療 に対する二・三の工夫．耳鼻臨床 $73: 655-661$, 1980.

3）山口展正: 内視鏡下の blowout fracture 整復術. JOHNS $16: 95-98,2000$.
4）山口展正：ESSによる吹き抜け骨折整復術。 JOHNS $12:$ 129-135, 1996.

5) Yamaguchi N, Arai S, Mitani $\mathrm{H}$, et al: Endoscopic endonasal technique of the blowout fracture of the medial orbital wall. Oper Techn Otolaryngol Head Neck Surg 2: 269-274, 1991.

6）東 祐史, 垣内 仁, 田村奈々子, 他 : 眼窩内側壁 骨折に対する内視鏡下整復術.耳鼻臨床 92：975980, 1999.

7）中之坊 学, 松永 毅, 古川太一，他：眼窩内側壁 骨折に対する内視鏡下鼻内手術の経験。頭頸部外科 $8: 157-161,1998$.

8）福島龍之, 高木伸夫, 大西弘剛, 他 : 眼窝内側壁骨 折の内視鏡下鼻内手術症例の検討。耳鼻臨床 91 ： 1121-1126, 1998.

9）内田 豊：吹き抜け骨折の治療上の問題点. 頭頸部 外科 $1: 101-106,1991$.

10）山口展正，森山 寛：陳旧性 BOF の内視鏡下整復 術. 頭頸部外科 $6: 43-48,1996$.

11）春名眞一，長船宏隆：小児慢性副鼻腔炎と鼻副鼻腔 外傷（眼窩吹き抜け骨折）。頭頸部外科 $9: 27-32$, 1999.

12）川内秀之：眼窩吹き抜け骨折の診断と治療。耳鼻臨 床 $89: 770-771,1996$.

13) Okinaka Y, Hara J, Takahashi M: Orbital blowout fracture with persistent mobility deficit due to fibrosis of the inferior rectus mucle and perimusclar tissue. Ann Otol Rhinol Laryngol 108 : 1174-1176, 1999. 